\title{
ZŁOTA LEGENDA I RZECZYWISTOŚĆ W pięćdziesięciolecie pracy naukowo-dydaktycznej Księdza Profesora Aleksandra Usowicza
}

Profesor Usowicz zatytułował jeden ze swych artykułów Złota legenda $i$ rzeczywistość. Zapożyczyłem to sformułowanie dla wspomnienia poświęconego Jego osobie, gdyż doskonale harmonizuje ono zarówno z tym, czym Profesor przez minione pięćdziesięciolecie się zajmował, jak i tym, kim był i jest dla uczniów oraz wychowanków. We wspomnieniu tym więcej będzie rzeczywistości niż legendy, chociaż trudno ją pominąć, pisząc o rzeczywistości dotyczącej pracy, dorobku i osobowości Profesora. Podstawę do niniejszego opracowania stanowią głównie drukowane prace i skrypty, ale nie tylko. By w pełni zaprezentować dorobek, jego specyfikę i oryginalność — oddamy również głos osobom bliskim Profesorowi oraz Jego uczniom. Jako jeden $\mathrm{z}$ nich, wielokrotnie czułem potrzebę wypowiedzenia wdzięczności za wszystko, czego osobiście doświadczyłem w spotkaniu z Profesorem Usowiczem. Jednak skromność Profesora, w ciągu wielu lat moich kontaktów z Nim, uniemożliwiała mi okazanie tej wdzięczności. Cieszę się zatem, że z okazji Jego jubileuszu naukowego mogę to uczynić przynajmniej w symboliczny sposób. Także i inni Jego uczniowie, przywołując doświadczenia swoich spotkań z Księdzem Usowiczem jako Profesorem, Kapłanem i Człowiekiem, powiedzą coś, co nie sposób wyczytać z Jego naukowych dzieł, a co jest nie mniej ważne w prezentacji Sylwetki Jubilata. Będzie więc w tym także odrobina legendy, dzięki której można lepiej i pełniej zobaczyć oraz zrozumieć rzeczywistość.

W swoim artykule Złota legenda i rzeczywistość Ksiądz Usowicz oparł się zapewne na znanym tekście greckiego filozofa: „Poezja jest bardziej filozoficzna i głębsza od historii" '. Podobna relacja zachodzi pomiędzy legendą i rzeczywistością, zwłaszcza legendą i rzeczywistością dotyczącą Osoby Profesora Usowicza. Jedna rzeczywistość buduje drugą, jedna z drugiej żyje. Rzeczywistość, przekraczając siebie, staje się legendą, legenda zaś nie jest zmyśleniem, lecz nieuchwytnym, tajemniczym wymiarem rzeczywistości, bez którego ta ostatnia sobą być nie może.

\footnotetext{
1 „Caritas” 5(1949) nr 50, s. 324; A ryst oteles, Poetyka, IX, 3.
} 
Swoje wspomnienie nazwałem ,złotą” legendą nie tylko dlatego, że dotyczy ona złotego jubileuszu, 50-lecia pracy naukowo-dydaktycznej. 50-lecie jest zaledwie okazją do tego, by tę złotą legendę wypowiedzieć.

Pisząc o Profesorze Usowiczu trudno oddzielić od siebie Jego działalność dydaktyczną i naukową czy też - nie działalność może — oddziaływanie, wpływ, promieniowanie osobowości, dzięki któremu naukowy i dydaktyczny trud stał się tak skuteczny. By jednak niczego nie pominąć, by możliwie najdokładniej przedstawić efekty pięćdziesięcioletniego trudu, omówimy w pierwszej części działalność dydaktyczną Profesora, w drugiej zaś naukową.

Ksiądz Profesor wykładał prawie wyłącznie w seminariach duchownych. Nawet wtedy, gdy był wykładowcą na Wydziale Teologicznym Uniwersytetu Jagiellońskiego, Jego słuchaczami byli zasadniczo kandydaci do stanu duchownego. Pracę w seminariach cenił wysoko. Nieraz mawiał, że nie zna drugiej instytucji na świecie, która byłaby w stanie tak przeorać umysły i serca ludzkie. Kiedy zarzucano mu, że jest romantykiem, niezmiennie odpowiadał: „Kto długo pracował w takich zakładach, nie może być romantykiem, jest realistą". I nadal obstawał z uporem przy swej tezie. Ceniąc instytucje, o których mowa, jednocześnie cenił nauczanie w tych instytucjach. Najbliżsi Jego współbracia mówili czasem, że nawet $\mathrm{w}$ największe święta nie ubierał się $\mathrm{w}$ nową sutannę, natomiast nie widziano, by kiedykolwiek poszedł na wykład w starej sutannie. Jego studenci opowiadają, że pewnego razu w czasie wykładu zamyślił się i powiedział: „Zapewne i na drugim świecie będą jakieś seminaria i wykłady”. Potem nie wracał już jednak nigdy do tej wypowiedzi. Myśląc o wykładach w seminarium, mawiał też nieraz, że chciałby umierać tak jak stare drzewa - na stojąco, a nawet na chodząco. I dodawał: „Stare drzewa umierają chodząc, a przynajmniej chodzą ich korony, gdy powieje silniejszy wicher".

Gdybyśmy szukali jakiegoś przydomka dla osoby Księdza Profesora, jak to czyniono w stosunku do filozofów w średniowieczu, to zapewne moglibyśmy Go nazwać nauczycielem, profesorem i mistrzem. On sam chętnie akceptował jedynie pierwszy tytuł, natomiast wzbraniał się przed dwoma następnymi uważając je za zbyt wygórowane. Ale nawet te opory $\mathrm{z}$ Jego strony świadczą o tym, że każdy $\mathrm{z}$ tych tytułów w pełni Profesorowi przysługuje.

Chcąc scharakteryzować wykłady Profesora postawimy sobie kolejno trzy pytania. W pierwszym będzie nam chodziło o to, $w$ jakich instytu- 
cjach i kiedy prowadził wykłady. Otóż pracę wykładowcy rozpoczął w Instytucie Teologicznym swojego Zgromadzenia. W kronice Meteora, pod datą 11 września 1936 r., czytamy, że w Krakowie na Stradomiu odbyła się inauguracja nowego roku akademickiego i że w czasie tej inauguracji powitano nowego wykładowcę, ks. Aleksandra Usowicza ${ }^{2}$. Następnego dnia, 12 września 1936 r., prowadził już normalne zajęcia. W Instytucie tym wykładał przez cały czas z dwoma przerwami, pierwsza przerwa trwała półtora roku, a druga siedem lat.

W okresie wojny wykładał w Częstochowskim Seminarium Duchownym $^{8}$ oraz $w$ Seminarium XX. Salwatorianów w Krakowie ${ }^{4}$. Studia te uchodziły za nauczanie $w$ podziemiu i za studia uniwersyteckie, za dalszy ciąg Wydziału Teologicznego Uniwersytetu Jagiellońskiego.

$\mathrm{Na}$ Wydzia!e Teologicznym UJ rozpoczął wykłady po śmierci księdza Konstantego Michalskiego w $1947 \mathrm{roku}^{5}$. Faktycznie wykładał siedem lat, prawnie zaś był pracownikiem Uniwersytetu do 1 kwietnia 1955 r., a więc jeszcze pół roku po likwidacji Wydziału. Do Wydziału jako części Uniwersytetu Jagiellońskiego bardzo się przywiązał - podobnie jak do swojej macierzystej uczelni, czyli do Instytutu Teologicznego swego Zgromadzenia. Na tyle na ile mógł, bronił istnienia tego Wydziału w ramach Uniwersytetu. Miał nawet zamiar przedstawić delegatowi władz państwowych, z którym przeprowadził rozmowę, taki projekt dalszego istnienia Wydziału jako integralnej części Uczelni Jagiellońskiej, który mógłby być przyjęty zarówno przez władze kościelne jak i państwowe. Po pewnym jednak namyśle zaniechał tego zamiaru. W sierpniu 1954 roku, ze strony władz państwowych, zaproponowano Księdzu Profesorowi katedrę filozofii na nowo utworzonej uczelni - na Akademii Teologii Katolickiej w Warszawie. Profesor nie przyjął jednak tej propozycji. W roku 1957 ks. Wincenty Kwiatkowski, ówczesny rektor ATK, proponował Profesorowi wykłady na tejże uczelni z psychologii religii na Wydziale Filozoficznym a także wykłady na Wydziale Teologicznym. Jednak i ta propozycja nie została przyjęta. Po roku 1956 trzy seminaria duchowne, mieszczące się wtedy $\mathrm{w}$ Krakowie, podzieliły się na odrębne studia. Profesor wykładał dalej w poszczególnych seminariach $\mathrm{z}$ dwoma przerwami, jedną sześcioletnią i drugą siedmioletnią. Dodajmy, że Rada Wydziału Teologicznego, jako Wydziału istniejącego już teraz tylko na prawie kościelnym, uznała te przerwy za pewnego rodzaju urlopy.

${ }^{2}$ Por. ks. J. Telu s CM, 35-lecie pracy naukowo-dydaktycznej ks. A. Usowicza w Instytucie Teologicznym Księży Misjonarzy w Krakowie, „Nasza Przeszłość” 1971, t. 35 , s. $183-185$.

${ }^{8}$ Por. „Częstochowskie Studia Teologiczne” 1974, t. 2, s. 176.

${ }^{4}$ Por. "ks. A. K i elbas a SDS (red.), Salwatorianie $w$ Polsce 1900-1975, Rzym-Kraków 1975, 144, 181.

5 Por. drukawane spisy wykładów UJ z lat 1947-1950 oraz Archiwum UJ S III 246. 
W latach 1959-1961 pracował w Seminarium w Gdańsku-Oliwie, a w latach 1971-1978 w Seminarium Gościkowie-Paradyżu. To ostatnie seminarium, należące do diecezji gorzowskiej, wychowywało wówczas alumnów także dla utworzonych w roku 1972 dwu diecezji: Szczecińsko-Kamieńskiej i Koszalińsko-Kołobrzeskiej. Przez cały rok akademicki 1950—51 dojeżdżał w każdą sobotę do seminarium w Kielcach ${ }^{6}$.

W latach 1952-1954 wykładał w studium teologicznym OO. Kapucynów w Krakowie ${ }^{7}$, a w latach 1955-1958 i od r. 1978 do dnia dzisiejszego $-\mathrm{z}$ przerwą jednego roku $-\mathrm{w}$ Seminarium OO. Paulinów w Krakowie Na Skałce.

Ponieważ pracował tak długo i w tak licznych instytucjach, dlatego nic dziwnego, że wśród uczniów Profesora znajdują się uczniowie nie tylko rozsiani po całej Polsce, lecz także i tacy, którzy pracowali lub pracują dosłownie na wszystkich kontynentach świata. Do grona słuchaczy Księdza Profesora należą także niektórzy księża biskupi, jak na razie - o ile dobrze policzyłem - w liczbie dwunastu.

Drugie pytanie dotyczy przedmiotów, jakie wykładał. Także i tutaj rozpiętość jest dość duża. Wykładał bowiem - jak dotychczas - nie tylko filozofię, ale także inne przedmioty, głównie teologiczne. Stopniowo, zależnie od potrzeby, obejmował swymi wykładami wszystkie działy filozofii, łącznie $\mathrm{z}$ tymi, które weszły do ratio studiorum dopiero w ostatnich latach. Pozostawil skrypty ze wszystkich traktatów filozoficznych. Większość spośród nich była wielokrotnie przerabiana i ogłaszana, czasem w formie mocno zmienionej, rozszerzanej lub skracanej. Podobnie było zresztą $\mathrm{z}$ innymi wykładanymi przedmiotami, $\mathrm{z}$ wyjątkiem historii Kościoła i patrologii.

Przy wykładach filozofii poświęcał wiele czasu każdemu traktatowi. Niektóre jednak działy opracowywał ze szczególnym zainteresowaniem, nawet wtedy, gdy nie poświęcał im jakiejś pracy naukowej. Do tych działów należą: metafizyka, historia filozofii i psychologia. W jednym z artykułów pisał: „Jak się mówi o psychologii głębi, tak samo można mówić i o filozofii głębi. Filozofią głębi jest metafizyka. Trzeba znać prądy w głębi oceanu nurtujące, by należycie poznać kształty fal, barwę, względnie inne zjawiska napowierzchniowe. Podobnie, zjawiska z życia codziennego, związane ze światem konkretnym zrozumiemy w całej pełni dopiero wtedy, gdy wyjdziemy poza nauki doświadczalne (dostarczające nam zresztą ogromu wiadomości) i wkroczymy w granice metafizyki. Dlatego wydaje się, że filozof piszący duże tomy na temat sporu o istnienie świata równie

${ }^{6}$ Por. Ksiega jubileuszowa 1727-1977. 250 lat Seminarium Duchownego w Kielcach, Kielce 1977, s. 472.

${ }^{7}$ Por. Kronika Konwentu Krakowskiego, 100, Kronika Seminarium, 83 c. Archiwum OO. Kapucynów w Krakowie. 
dobrze służy konkretnym zjawiskom życia, jak matka pochylająca się nad kołyską swego dziecka" 8 .

O historii filozofii wyrażał się, iż żadną miarą nie jest ona zbiorem błędów myśli ludzkiej, ale że - przeciwnie - można się przy niej zapoznać z całą problematyką filozoficzną. Miał przekonanie, że poszczególne systemy występujące $w$ historii filozofii są nie tyle sprzeczne czy przeciwne sobie, lecz wzajemnie się uzupełniają. Sądził, że stare idee, o których mówi historia filozofii mogą się niejako wciąż odradzać do nowego życia i stanowić zasady postępowania w życiu jednostkowym i zbiorowym. Często przytaczał na wykładach następujące zdanie S. Radhakrishnana: „Idee wielkich myślicieli nie starzeją się. Z nich to czerpie siły żywotne postęp, który pozornie je zabija. Najstarożytniejsze pomysły zaskakują nas niekiedy swym zdumiewająco nowoczesnym charakterem, gdyż zdolność wglądu w istotę rzeczy nie zależy od epoki" ". Nieraz też cytował i krótko analizował w trakcie wykładów inne, podobne zdanie, pochodzące od E. Gilsona: „Idee nigdy nie umierają; są wieczne i zawsze gotowe do nowego życia w umysłach, które ich potrzebują, i na podobieństwo starych nasion mogą znowu kiełkować, gdy padną na urodzajną glebę" ${ }^{10}$.

Z historii filozofii opracował skrypt w trzech częściach. Część pierwsza zawiera historię filozofii starożytnej, greckiej i częściowo rzymskiej, nie obejmuje filozofii starożytnej innych narodów, choć w niektórych latach uwzględniał $\mathrm{w}$ wykładach filozofię starożytną innych narodów orientalnych, zwłaszcza filozofię indyjską i chińską. Najczęściej jednak wykłady $\mathrm{z}$ historii filozofii starożytnej organiczały się do historii myśli greckiej z uwzględnieniem także filozofów rzymskich. Profesor uważał, że filozcfia innych narodów starożytnych należy raczej do historii religii. Zresztą sądził, że filozofia tamtych narodów wywarła znacznie mniejszy wpływ na kulturę zachodnioeuropejską aniżeli filozofia grecka. Druga część skryptu obejmuje filozofię nowożytną, trzecia zaś filozofię współczesną, począwszy od Bergsona. Na końcu tej trzeciej części czytamy uwagę: ,W drugim wydaniu niniejszego skryptu doda się przed każdym rozdziałem literaturę przedmiotu, ze szczególnym uwzględnieniem dzieł i artykułów w języku polskim, na końcu zaś rozdziałów umieści się teksty wybrane wybitniejszych myślicieli". Zamiar ten, jak dotychczas, nie został jednak zrealizowany.

Psychologię wykładał od początku, z niewielkimi przerwami, i wykłada ją nadal. W pierwszych latach uwzględniał zarówno psychologię empirycz-

${ }^{8}$ Ks. A. U s owic z, Zarys metafizyki ogólnej, „Tygodnik Powszechny” 5(1949), nr 17 , s. 4.

${ }^{9} \mathrm{~S} . \quad \mathrm{R}$ adhakrishna n, Filozofia indyjska, I, Warszawa 1958, s. 45.

10 E. Gilson, Historia filozofii chrześcijańskiej $w$ wiekach średnich, Warszawa 1966 , s. 525 . 
ną i tzw. psychologię racjonalną. W późniejszych latach ograniczył się w tych wykładach do psychologii w ścisłym tego słowa znaczeniu, tzn. empirycznej. Sam nie przeprowadzal eksperymentów psychologicznych. Długo jednak studiując i wykładając psychologię zdobył duży zasób wiedzy z tej dziedziny, tak że można Go zaliczyć do tej grupy osób w Polsce, która najlepiej orientuje się $\mathrm{w}$ całokształcie problematyki psychologii teoretycznej.

Już od roku 1948, najpierw na Wydziale Teologicznym UJ a potem także w Instytucie swojego Zgromadzenia, wykładał przez kilka lat psychologię religii. Teraz, jak sam mówi, nie wykładałby jej już w taki sam sposób. Trzeba jednak powiedzieć, że $\mathrm{w}$ tamtych czasach wykłady $\mathrm{z}$ tego przedmiotu były w pewnym znaczeniu pracą pionierską. Ksiądz Franciszek Manthey w swym Wprowadzeniu $w$ psychologie religii daje taka uwagę: „W czasach nowych dopiero ks. Usowicz, profesor UJ w Krakowie, wydał skrypt hektografowany pt. Psychologia religii (Kraków 1949), którego dyspozycję ze względu na ważność przedmiotu tu podaje" "11. Dodajmy, że obok tej pierwszej wersji skryptu z psychologii religii, w roku 1951 ukazała się wersja druga, znacznie zmieniona i rozszerzona.

Po wojnie, przez kilka lat w Instytucie własnego Zgromadzenia i przez parę lat na Skałce, wykładał dydaktykę i teorię wychowania. Zresztą uważał ten przedmiot za pokrewny filozofii, a nawet $\mathrm{w}$ wielu jego partiach za ściśle filozoficzny lub psychologiczny. Wprawdzie dzielił pedagogikę (najszerzej pojętą) na dwie części: na teorię nauczania i teorię wychowania, to jednak ściśle łączył je ze sobą. Uważał bowiem, że czynności dydaktycznych nie da się ściśle oddzielić od czynności wychowawczych. Z jednej bowiem strony, czynności dydaktyczne wpływają na proces wychowania tak ze strony a) treści, jak i b) funkcji uczenia się. Treść podawana przy nauczaniu ukazuje dla woli ludzkiej cele, wartości i zasady postępowania oraz podsuwa motywy dla tego postępowania. Funkcja zaś uczenia się z konieczności wpływa na życie uczuciowe człowieka i na jego wolę, skłania np. do sumienności, cierpliwości, do pracy systematycznej i do akrybii. Z drugiej strony, wychowanie czy samowychowanie, właściwie pojęte i praktykowane, wpływa dodatnio na czynności dydaktyczne. Od charakteru człowieka, od wyrobienia jego osobowości w dużym stopniu zależy funkcja uczenia i uczenia się.

Wykłady Księdza Profesora z dydaktyki i teorii wychowania wiązały się ściśle z Jego zainteresowaniami teoretyczną stroną czynności dydaktycznych i wychowawczych. Często, zarówno przy osobistej lekturze jak i przy analizie tekstów klasycznych w czasie wykładów, powracał do 30.

${ }^{11}$ Ks. F. Manthey, Wprowadzenie $w$ psychologię religii, Pelplin, bdw., s. 
dialogu św. Augustyna $O$ nauczycielu. Nieraz też dokonywał refleksji nad dwoma podobnymi tekstami św. Tomasza z Akwinu, nad jednym zawartym w Sumie teologicznej i nad drugim - w Quaestiones disputatae.

W czasie wojny, ponieważ wymagały tego warunki, podjął wykłady $\mathrm{z}$ historii Kościoła. Wyłożył w ciągu trzech lat całą historię Kościoła powszechną i historię Kościoła w Polsce. W tym samym czasie, a także po wojnie, na Wydziale Teologicznym UJ wykładał Wstęp do teologii, w którym stosunkowo obszernie podał historię teologii, akcentując szczególnie idee i cechy charakterystyczne prądów teologicznych i poszczególnych teologów. W Instytucie własnego Zgromadzenia, w czasie wojny i w pierwszych latach po wojnie, podjął wykłady z traktatu o wierze (De fide), który miał stanowić jakby tło dla wykładów innych traktatów dogmatycznych. W tym samym czasie wykładał traktat De Deo uno i o Trójcy świętej (De Deo trino). Po wojnie w Instytucie własnego Zgromadzenia wykładał przez szereg lat teologię fundamentalną (apologetykę). Opracowany skrypt z tego przedmiotu obejmuje trzy części: pierwsza mówi o religii i objawieniu w ogólności, druga o chrystologii (z punktu widzenia apologetycznego) a trzecia o Kościele.

W Seminarium w Gdańsku wykładał: patrologię, teologię fundamentalną i podstawy teologii moralnej (principia).

W latach 1964-1969 wykładał w Instytucie własnego Zgromadzenia (obok niektórych traktatów filozoficznych) również teologię życia wewnętrznego. W związku z tymi wykładami opracował historię teologii życia wewnętrznego (kładąc główny nacisk na historię idei) oraz osobny skrypt (w kilku częściach) systematycznej teologii życia wewnętrznego.

$\mathrm{Na}$ Wydziale Teologicznym (na prawie kościelnym), a potem na Wydziale Filozoficznym Krakowskiej Uczelni Teologicznej, miewał też wykłady monograficzne. Na Wydziale Filozoficznym odbyły się w latach 1978-1986 wykłady monograficzne na następujące tematy: wybrane zagadnienia $\mathrm{z}$ filozofii kultury, problem wojny i pokoju, zagadnienie praw człowieka, współczesny ateizm, Etyka Nikomachejska.

W roku 1955-56 podjął wykłady w seminarium swego Zgromadzenia z bibliologii, czyli z nauki o książce, zwłaszcza o starej książce. Wykłady te łączyły się z pracą wykładowcy $\mathrm{w}$ bibliotece. Po wojnie, przy współudziale wielu osób mieszkających w Krakowie na Stradomiu, zorganizował uporządkowanie biblioteki tego domu. Sam spisał tysiące tytułów a jeszcze większą ilość tytułów poprawił. Pracując w Gdańsku, własnoręcznie spisał całą, niedużą jeszcze wtedy, bibliotekę tamtejszego seminarium. W czasie pobytu w Gościkowie-Paradyżu wykorzystywał niektóre miesiące wakacyjne do porządkowania tamtejszej biblioteki.

Pracę $\mathrm{w}$ bibliotekach wiązał ściśle $\mathrm{z}$ działalnością dydaktyczną. I rze- 
czywiście praca ta znacznie pomagała w tej działalności Profesorowi przy prowadzeniu wykładów, jego słuchaczom zaś przy uczeniu się. Co więcej, praca ta pomagała funkcji dydaktycznej na innej jeszcze drodze, a mianowicie pozwalała Profesorowi na dokonywanie pewnych odkryć w zakresie historii książki rękopiśmiennej lub drukowanej, np. przy porządkowaniu biblioteki stradomskiej odkrył drugi w Polsce, nie znany dotychczas, pelny tekst dziełka przypuszczalnie Szymona Starowolskiego, tekst opisujący oblężenie Krakowa przez króla szwedzkiego.

Przejdźmy teraz do trzeciego pytania w ramach pierwszej części naszego artykułu, a mianowicie do pytania o sposób nauczania.

Początkowo, przez długie lata, Ksiądz Profesor prowadził wykłady w oparciu o własne skrypty. Później, gdy prawie każdemu studentowi mógł dać do ręki jakiś drukowany podręcznik - posługiwał się tym podręcznikiem. Powyższą zmianę słuchacze przyjmowali jednak negatywnie. Zresztą nie należy się temu dziwić. Dla początkujących studentów (a prawie zawsze wykładał na pierwszym i drugim roku) współczesne podręczniki były $\mathrm{w}$ wielu miejscach niezbyt czytelne i trudne do opanowania. Wykładowca nie posługiwał się przy wykładzie notatkami. W związku z tym powstała legenda, że ma bardzo dobrą pamięć. Sam Profesor twierdzi natomiast, że nigdy nie posiadał zbyt dobrej pamięci. Według Niego, po prostu łatwiej jest najpierw ułożyć schemat wykładu w myślach, podać go następnie we formie ustnej, a dopiero potem ewentualnie go spisać. Odwrotna kolejność — od spisania do wypowiedzi w postaci żywego słowa - nie odpowiadała usposobieniu wykładowcy. Na wykładach mówił zawsze w liczbie mnogiej: omówiliśmy taki a taki temat, postanowiliśmy to a to itd. Najprawdopodobniej nikt ze studentów Księdza Profesora nie przypomina sobie, by używał On kiedykolwiek wyrażeń: moja praca, ja to zrobiłem itd. Taka forma wypowiedzi byłaby sprzeczna z najgłębszym przekonaniem Profesora, według którego na wykładach nie podaje się własnej doktryny, że jest ona zawsze dziedzictwem wielu pokoleń. Ksiądz Profesor sądził zresztą, że przy wykładach współpracują także studenci: on ich naucza, ale i sam wiele się od nich uczy, i to nawet wówczas, gdy dany wykład przyjmują w milczeniu. Niektórzy snują w związku z tym domysły, czy przyjęta przez Niego postawa dydaktyczna nie stanowiła przypadkiem jakiejś bariery dla Jego osobistej twórczości. Bogata osobowość Profesora sprawia jednak, że zazwyczaj dość prędko gubią się oni w tych domysłach.

Wykłady Profesora miały zasadniczo charakter teoretyczny, choć było jednocześnie widać, że ma on również na oku dalsze perspektywy praktyczne. Wykładowca, jak się zdaje, nie posiadał daru udzielania uwag czy zaleceń praktycznych. Chodziło mu głównie o to, by podać możliwie głębokie a zarazem żywe ogólne idee i ogólne zasady. Zresztą, wykła- 
dając $w$ psychologii zagadnienie tzw. transferu, opowiadał się nie za teorią tzw. wspólnych składników, lecz za teorią ogólnych pojęć i zasad. Uważał bowiem, zgodnie z tendencją współczesnej dydaktyki, że konkretne sytuacje i szczegółowe problemy można łatwiej opanować, jeśli się je niejako włoży w ramy ukształtowanych, ogólnych pojęć i zasad. Akcentująe w swoich wykładach teorię był równocześnie przekonany, że filozofia, teologia i każdy dział nauki tylko wtedy dobrze przysłuży się praktyce, kiedy będzie możliwie jak najlepszą teorią, teorią pogłębioną. Wiele razy przypominał odezwę prezydenta Stanów Zjednoczonych, Herberta Clarka Hoovera nawołującą do uprawiania tzw. nauki czystej, i to w imię jej zadań utylitarnych. Każda nauka dopiero wtedy stanie się naprawdę w pełni użyteczną, gdy będzie w pewien sposób nauką antyutylitarną ${ }^{12}$.

Swoje zajęcia prowadził Ksiądz Profesor w sposób tradycyjny, chociaż doskonale orientował się w różnych współczesnych formach wykładu. $\mathrm{Na}$ ogół Jego wykłady nie pobudzały słuchaczy do stawiania pytań. Zazwyczaj nie pojawiała się też na nich dyskusja. Można jednak sądzić, że ze względu na ich strukturę, treść i formę zewnętrzną nie były to wyłącznie monologi. Wydaje się, iż wielu studentów podczas wykładu Profesora stawiało sobie w ciszy różne pytania, które potem niejednokrotnie wywoływały wśród nich żywe dyskusje.

Wykładowca czerpał nierzadko z bogactwa myśli zawartego w Sumie teologicznej św. Tomasza. M.in. zaglądał wiele razy do pierwszych jej zdań, do ogólnego prologu. Doktor Anielski pisał tam:

Nauczyciel prawd wiary katolickiej winien wykładać je mie tylko już obznajomionym z nimi słuchaczom, ale do niego należy uczyć ich także i początkujących studentów, stosownie do słów Apostoła: Jako niemowlętom w Chrystusie mleko wam datem, a nie pokarm staty (1 Kor 3,1). Dlatego też, $\mathrm{w}$ tym ato dziele zamierzamy to co obejmuje religia chrześcijańska, w taki sposób podać, by nadawała się przede wszystkim do nauczania początkujących. Zauważyliśmy bowiem, że dla początkujących słuchaczy dużą przeszkodą w zdobywaniu tej nauki stanowią dzieła różnych teologów: już to dlatego, że są nadmiernie przeładowane bezużytecznymi zagadnieniami, artykułami i dowodami, już to dlatego, że zagadnienia, z jakimi owi początkujący winni koniecznie się zapoznać, nie są podane systematycznie: według uporządko'wanej kolejności nauk czy traktatów, ale omawiane są albo w związku z komentowaniem dzieł, albo z okazji dysputy; już to wreszcie dlatego, że częste powtarzanie tego samego budziło $w$ ich umysłach nudę i zamęt. Ufni w pomoc Bożą i starając się uniknąć tych i podobnych niedociągnięć, będziemy usiłowali krótko i jasno - o ile na to sama rzecz pozwoli - wyłożyć wszystko, co zakresem swoim obejmuje nauka święta ${ }^{13}$.

12 Por. S. Os s ow ski, $N$ nauce, Warszawa 1967, s. 105.

13 Por. M. Grabmann, Wstęp do Sumy teologicznej świętego Tomasza $z$ Akwinu, Lwów 1935, s. 60-73. 
Wydaje się, że powyższy tekst był jak gdyby wzorem w działalności dydaktycznej Księdza Profesora, tym bardziej iż sposób przedstawiania zagadnien, o których $\mathrm{w}$ tym tekście mowa, odpowiadał strukturze umysłowej wykładowcy. Nic więc dziwnego, że w swoich wykładach Profesor starał się, by przy danym temacie podać przede wszystkim elementy istotne, układając je w architektoniczną całość. Następnie, myśl była wyrażana w formie bardzo zwięzłej, czasem stylem niemal telegraficznym. Niekiedy jednak wykładowca zapalał się, odchodził na kilka chwil od formy zwięzłej i wyrażał się nawet językiem prozy poetyckiej. W związku z tym wśród studentów można było usłyszeć opinię, że w czasie wykładu Profesor staje się jakby zupełnie innym człowiekiem. W swoim normalnym życiu jest podobny do mrówki, która w milczeniu gromadzi wciąż jakiś materiał, na wykładzie zaś staje się orłem unoszącym się ponad szczytami gór. Dążył też do jasności, pragnął, by nawet najtrudniejsze tematy stawały się dostępne dla umysłów słuchaczy. Jasność starał się jednak zawsze łączyć z pogłębianiem danego zagadnienia.

W późniejszych zwłaszcza latach wymieniony sposób wykładu prawie z reguły ubogacany był pewnymi dodatkami. Profesor miał zwyczaj, przynajmniej od czasu do czasu, odczytywać jakąś myśl z klasycznych tekstów filozoficznych i w krótkich słowach dawać do niej komentarz. Te krótkie komentarze były nieraz wyjątkowo żywe a nawet - można powiedzieć - oryginalne. Ale też z reguły ich nie notował. Innym dodatkiem do wykładów były informacje o książkach lub świeżo wydanych artykułach. I tutaj wykładowca umiał $\mathrm{w}$ krótkich słowach dać ogólny przegląd tematyki danej książki lub podkreślić zasadnicze jej myśli. Lubił wreszcie poświęcać nieco czasu na tzw. aktualia. Od strony filozoficznej naświetlał w nich pewne wydarzenia współczesne - głównie dotyczące naszego kraju - sięgając często nawet do filozofii prawa. Np. w ostatnich latach w tego rodzaju aktualiach omówił właściwie wszystkie zasadnicze idee występujące $\mathrm{w}$ powojennych dokumentach prawa międzynarodowego.

Jest znamienne, że powyższe cechy wykładów Księdza Profesora zdaniem Jego uczniów - w ogóle z upływem lat nie znikały, lecz jak gdyby narastały. Coś z tego, jak się zdaje, miał zresztą w swej świadomości sam wykładowca. Pewnego bowiem razu umilkł na moment w czasie wykładu, objął rękami głowę i powiedział: „Ta głowa najwyraźniej rośnie". Natychmiast jednak odpędził od siebie tę chwilę roztargnienia, spostrzegając zapewne, że za daleko posunął się w rzekomym samochwalstwie.

Oczywiście w ramy działalności dydaktycznej, oprócz wykładów, wchodzi jeszcze wiele innych zajęć. Gdy chodzi o Księdza Profesora, trzeba tu szczególnie podkreślić ogrom Jego pracy, która była związana z pi- 
saniem wyjątkowo dużej liczby recenzji rozpraw magisterskich, licencjackich, doktorskich, habilitacyjnych oraz przy przewodach odnoszących się do nominacji profesora nadzwyczajnego i zwyczajnego. Recenzje te są przechowane w Archiwum UJ, w archiwum Wydziału Teologicznego (na prawach kościelnych), a potem w archiwum Krakowskiej Uczelni Teologicznej. Dla przykładu wspomnijmy tylko niektóre recenzje. W dniu 30 listopada 1953 roku, w dziekanacie Wydziału Teologicznego UJ (Collegium Novum), Ksiądz Profesor odczytał swą recenzję pracy habilitacyjnej późniejszego papieża Jana Pawła II ${ }^{14}$. Pisał także recenzję z dorobku naukowego księdza Antoniego Witkowiaka przy jego habilitacji (1975), jak również recenzję rozprawy habilitacyjnej o. Dominika, Eugeniusza Widera OCD (1983). Gdy chodzi o przewody związane z nominacjami na stanowiska pracowników naukowych, dał ocenę dorobku naukowego obecnego Rektora Krakowskiej Uczelni Teologicznej, ks. bpa Mariana Jaworskiego (1975) oraz obecnego Dziekana Wydziału Filozoficznego, księdza Tadeusza Wojciechowskiego (1975). W obu wypadkach oceny poprzedzały nominację na stanowisko profesora zwyczajnego. Ponadto napisał recenzję o pracach naukowych poprzedniego dziekana Wydziału Filozoficznego ks. Józefa Tischnera przed jego nominacją na profesora nadzwyczajnego (1980). W tym roku Rada Wydziału Filozoficznego wyznaczyła Profesora na recenzenta prac naukowych ks. Józefa Tischnera przed nominacją na profesora zwyczajnego.

Przejdźmy teraz do drugiej części naszego artykułu i spróbujmy szkicowo omówić działalność naukową Księdza Profesora. Chodzi nam tu zasadniczo o prace drrukowane, jako że zostały one poddane uwagom krytycznym i ocenie szerszego grona osób zajmujących się określoną tematyką ${ }^{15}$.

Biorąc pod uwagę 50 lat pracy, trzeba powiedzieć, że liczba rozpraw Profesora nie jest zbyt duża. Można by postawić pytanie, dlaczego tak się stało. Zapewne wiele było czynników, które na to wpłynęły. Trudno jest nam tutaj wchodzić w wewnętrzny świat Księdza Profesora, a trzeba by było tam wglądnąć, a nie tylko brać pod uwagę sytuacje zewnętrzne, by sprawiedliwie ocenić Jego dorobek naukowy. W wielu wypadkach proszono Profesora o napisanie rozprawy czy artykułu. W danych jednak warunkach brakowało $\mathrm{Mu}$ czasu na opracowanie proponowanego

14 Zob. ks. A. Boniecki, Kalendarium życia Karola Wojtyły, Kraków 1983, S. $122-124$.

15 Pierwszy wykaz prac drukowanych Profesora Usiowicza podał ks. J. Telus, art. cyt., s. $185-188$. 
tematu i nie skorzystał $\mathrm{z}$ okazji. Nie jest wykluczone, iż w niejednym przypadku mógłby pokonać trudności. Jednakże nie chciał publikować pracy, która - Jego zdaniem - była niedojrzała. W innych sytuacjach zdarzało się, że napisał już taki lub inny artykuł, lecz z różnych powodów nie ukazał się on drukiem. A ponieważ Profesor miał zwyczaj pisania artykułów w jednym tylko egzemplarzu, dlatego często ulegały one zagubieniu.

Nie można powiedzieć, by lekceważył owoce swej pracy. Zdaje się jednak, że często ich nie doceniał. Bywało, że opracowany już lub dość dobrze naszkicowany artykuł przeleżał dziesiątki lat wśród papierów Księdza Profesora i nigdy nie doczekał się ogłoszenia drukiem. Zdarzało się też, że pracowicie zebrane teksty i inne materiały przekazywał komuś innemu, by ułatwić mu start naukowy.

Być może, były również jeszcze jakieś inne, głębsze powody uchylania się od częstych publikacji. W tym kontekście zacytujmy pewne zdania charakteryzujące działalnośćś naukową jednego z filozofów i socjologów amerykańskich (Georg H. Mead), o którym wiadomo, że ogłosił drukiem niewielką liczbę prac. Napisano o nim, że ,stanowi rzadki w nauce nowoczesnej przypadek uczonego, który oddziaływał przede wszystkim jako nauczyciel, i obfity a przy tym doniosły dorobek swej naukowej aktywności przekazywał żywym słowem, czy to przekonany, jak starożytny filozof grecki, o przewadze wiedzy bezpośrednio docierającej z ust nauczyciela do uszu uczniów, czy też powodujący się psychologicznym powściągiem przed ostatecznym i nieodwołalnym utrwaleniem myśli, które chciał rozwinąć i wzbogacić, koncepcji, które dopiero doskonalił i precyzował w stymulującej atmosferze audytoryjnej sali" ${ }^{16}$. Nie ulega wątpliwości, że coś z myśli zawartych w tym tekście można przypisać działalności naukowej Profesora. Tym bardziej, że jedna z jego bardzo drobnych prac, napisana już w roku 1933, nosi tytuł Pismo $i$ Platon ${ }^{17}$.

Zostawmy już jednak ten temat na boku, a postarajmy się jakoś sklasyfikować i krótko scharakteryzować drukowane prace Księdza Profesora. Oczywiście, można się posługiwać - także i w odniesieniu do prac naukowych - różnymi zasadami klasyfikacji. Jako kryterium podziału weźmy podstawę bardzo prostą, a mianowicie objętość rozpraw. W pierwszej grupie umieszczamy prace w formie książek. Druga grupa obejmuje rozprawy i artykuły, mniejsze lub większe, nie mające charakteru książek. Do trzeciej grupy zaliczymy kilka zaledwie tekstów możemy je nazwać drobiazgami. Odróżniają się one od prac dwu pierwszych grup m.in. tym, że są dialogami.

\footnotetext{
16 A. Kłoskowska, Behawioryzm spoleczny G. H. Meada, [w:] G. H. M e a d, Umyst, osobowość $i$ spoleczeństwo, Warszawa 1975, XI-XII.

17 „Meteor” 25(1933) s. 67-68.
} 
W pierwszej grupie mamy cztery książki. Pierwsza zajmuje się zagadnieniem definicji u Arystotelesa $\mathrm{z}$ uwzględnieniem jego komentatorów. Tytuł tej książki brzmi: De Aristotelis circa definitionem doctrina commentatorum sententiis illustrata. Książka ta, obszerna i napisana z dużą erudycją, w części tylko ukazała się drukiem ${ }^{18}$. W rozprawie tej autor omawia głównie teksty Arystotelesa zawarte w Topikach, Analitykach wtórych i w Metafizyce, bo tam przede wszystkim znajdują się teksty Filozofa nt. definicji. Zgodnie $z$ tytułem rozprawy, autor uwzględnił poglądy wybitniejszych komentatorów Arystotelesa. Podajmy tutaj pewien szczegół. W czasie pisania swej pracy autor zaczął się uczyć języka arabskiego, sądząc, że jego znajomość ułatwi Mu lepsze zrozumienie myśli komentatorów arabskich. Wkrótce jednak odstąpił od studium tego języka uważając słusznie, że istnieją doskonałe tłumaczenia łacińskie tekstów arabskich. Przytoczyliśmy tutaj ten szczegół, by podkreślić, że poważnie i sumiennie opracowywał swoją tezę. Rzecz ciekawa, że autor pracy, odznaczający się darem syntezy, w tym wypadku wykazał też zdolność do bardzo daleko idącej analizy. Maszynopis pracy wypełniony jest bowiem przypisami w języku greckim i drobiazgową nieraz analizą ważniejszych tekstów dotyczących definicji.

Do problematyki logicznej w pracach naukowych w zasadzie już później nie wracał. Zgodnie z tradycją filozofii klasycznej, nie zaliczał logiki do działów ściśle filozoficznych. Uważał wprawdzie logikę za ważne narzędzie przy studium filozofii, ale tylko za narzędzie. Oczywiście sądził, że powinni znaleźć się ludzie opracowujący to narzędzie, sam jednak nie odczuwał powołania do pracy naukowej w tym kierunku. Zresztą do tzw. logiki formalnej, ujętej w formie logiki matematycznej, miał pewne zastrzeżenia, choć - jak wiemy - przez długie lata zajmował się nią w swej działalności dydaktycznej. Co więcej, napisał artykuł o jednym z najwybitniejszych twórców tej logiki, o Janie Łukasiewiczu ${ }^{19}$. Wspomniane zastrzeżenia do logiki formalnej łączą się z pewną dyskusją, jaka się pojawiła między przedstawicielami szkoły lwowsko-warszawskiej a opinią Romana Ingardena ${ }^{20}$. Ksiądz Profesor skłaniał się raczej do opinii Ingardena.

Tytuł drugiej książki brzmi: Układ cnót $i$ wad $w$ związku $z$ życiem uczuciowo-popędowym u Arystotelesa i św. Tomasza z Akwinu. We wstępie do tej pracy autor pisze: „Humanista Ludwik Vives zarzucal starożytnym, że zbyt mało uwagi przykładali do teorii uczuć. On sam dopiero

18 „Collectanea Theologica 19(1938) s. 273-317; „Divus Thomas” Piac. 42(1939) s. $114-119$.

${ }_{19}$ Zob. Listy Jana Łukasiewicza do księdza Konstantego Michalskiego, ,Analecta Cracoviensia" 2(1970) s. 117-129.

${ }_{20}$ Por. R. Ingarden, $Z$ teorii języka $i$ filozoficznych podstaw logiki, Warszawa 1972 , s. $191-221$. 
miał rozwinąc $w$ sposób subtelny i dokładny tę dziedzinę psychologii. Rzeczywiście wspomniany autor całą trzecią księgę swego dzieła De anima et vita poświęcił afektom, gdzie podał wiele wskazań praktycznych, ważnych zwłaszcza dla pedagogiki. Jeśli jednak zwrócimy uwagę na źródła filozofii perypatetyczno-scholastycznej, zauważymy, że sąd Vivesa, tak często później powtarzany przez historyków filozofii nowożytnej, jest w dużej mierze przesadzony. Przede wszystkim naukę Arystotelesa i świętego Tomasza należałoby $\mathrm{z}$ tego zarzutu wykluczyć. Omawianie uczuć spotykamy i w psychologii i w etyce perypatetycznej. Między innymi klasyfikacja cnót i wad ma u Arystotelesa i św. Tomasza wyraźne tło uczuciowe" ${ }^{21}$.

Po omówieniu całej problematyki, tzn. po ukazaniu, jak kształtują się w człowieku zalety moralne i dyspozycje wadliwe w oparciu o świat uczuć, autor na końcu dodaje: „Jedna główna myśl płynie z całej powyższej nauki Arystotelesa i św. Tomasza z Akwinu: życie uczuciowo-popędowe jest bogatą energią, z której można dobrze lub źle skorzystać [...] Z tego punktu widzenia nauka Arystotelesa i św. Tomasza o układzie cnót i wad w związku z życiem uczuciowo-popędowym staje się częścią składową charakterologii i psychologii wychowowczej w systemie filozofii chrześcijańskiej" "22. Zwracając uwagę na tekst książki i wymienione cytaty możemy, zgodnie z terminologią współczesną, zaliczyć tematykę omawianej pracy do zagadnienia formowania osobowości, rozpatrywanego pod jednym $\mathrm{z}$ wielu aspektów.

Tematyka trzeciej książki pt. Tomistyczna sublimacja uczuć w świetle nowożytnej psychologii jest spokrewniona z problematyką drugiej książki. Praca jest rozprawą habilitacyjną przedstawioną na Wydziale Teologicznym Uniwersytetu Jagiellońskiego.

Autor rozprawy idzie torem nakreślonym przez ks. Michalskiego w trzech następujących artykułach: Eros $i$ logos u Dantego (1936), La sublimation thomiste (1937), Dusze dać (1945). Część pierwsza rozprawy, jak pisze autor w przedmowie, „ma charakter ogólny i przedstawia fakt sublimacji uczuć i sposoby sublimacji tak w nowożytnej jak i tomistycznej filozofii. Wśród nowożytnych myślicieli bierze praca pod uwagę głównie Freuda, Schelera, Kretschmera i przedstawicieli psychologii pedagogicznej. Część druga, mająca charakter specjalny, stara się ując sprawności moralne pod kątem widzenia procesu sublimacji. Ponieważ według św. Tomasza cnoty męstwa i umiarkowania wprost uszlachetniają uczucia, dlatego te cnoty głównie autor rozpatruje. Także i w tej części naświetla się naukę tomistyczną przez prawdy a nawet i błędy nowożytne" ${ }^{23}$. Autor

$21 \mathrm{Ks}$. A. Us ow ic z, Układ cnót $i$ wad $w$ zwiazku z życiem uczuciowo-popędowym u Arystotelesa $i$ św. Tomasza $z$ Akwinu, Kraków 1939, s. 5.

22 Tamże, s. 134.

23 Tenże, Tomistyczna sublimacja uczuć $w$ świetle nowożytnej psychologii, Kraków 1946, Wstęp. 
dodaje jeszcze: „Praca ma charakter filozoficzny. Dlatego nie obejmuje zagadnień sublimacji, związanych z teologią. Autor wyczuwa jednak, że sublimacja ma szersze horyzonty, wykracza daleko poza porządek naturalny. Chociażby nawet teologowie nie chcieli przyjąć terminu sublimacji, muszą przyznać, że idea sama jest ideą płodną dla teologii" ${ }^{24}$.

Myśl poruszoną w zacytowanym ostatnim zdaniu autor rozwinął szkicowo, choć pozostając głównie w kręgu tematów filozoficznych, w niewielkiej rozprawie, która poszła o krok dalej w stosunku do książki om?wianej. W rozprawie tej analizuje treść terminu ,redundantia”, terminu oznaczającego coś w rodzaju procesu rozlewności psychicznej. Rozprawa ta, jak dotychczas, nie ukazała się drukiem, choć pewne jej ślady znajdujemy w drukowanych artykułach Profesora.

Dwie ostatnie książki Ksiądz Profesor przesłał ówczesnemu biskupowi lubelskiemu Stefanowi Wyszyńskiemu. Ks. bp Wyszyński, dziękując za nie, napisał do autora list, w którym zachęca go, by dalej pracował nad problematyką zawartą w obu dziełach. W liście wspomina m.in. o niedawnej śmierci ks. Władysława Korniłowicza, który wspaniale orientował się w myśli św. Tomasza w tej dziedzinie. Dodaje zarazem, że ks. Korniłowicz „,mógłby był napisać piękne rzeczy, ale nie miał łatwości pióra. Mówił pięknie, pisał z trudem. Nieraz namawiałem go w czasie wojny, by pozostawił chociaż analizę tomistyczną czynu ludzkiego. Nie udało się. Bardzo się cieszę, że ks. Profesor w tej dziedzinie pracuje, bo może doczekamy się i dalszych dzieł, które dadzą nam to, co usiłują zrobić poza filozofią chrześcijańską socjologowie polscy [...] Bardzo się cieszę, że ks. Profesor jest wierny swemu zainteresowaniu i po rozprawie doktorskiej poszedł w swej nowej pracy krok dalej. Niech Duch Swięty wspiera" ${ }^{25}$.

Czwarta książka, napisana wspólnie z ks. Kazimierzem Kłósakiem, poświęcona jest księdzu Konstantemu Michalskiemu (Kraków 1949). Ksiądz Profesor Usowicz omówił w niej życiorys i dzieła ks. Michalskiego. W ostatnich dwóch rozdziałach naszkicował idee przewodnie jak również temperament i charakter ks. Michalskiego. Do książki dołączono bibliografię prac drukowanych i spis rękopiśmiennych dokumentów odnoszących się do życia i działalności wybitnego uczonego. Ten wykaz rękopisów jest szczególnie cenny i pozostanie na długie lata wartościowym źródłem dla historii kultury naszego kraju.

Z wymienioną książką łączy się ściśle szereg późniejszych artykułów dotyczących także życia, osobowości i twórczości ks. Michalskiego oraz prace związane $\mathrm{z}$ ogłaszaniem drukiem tekstów ks. Michalskiego. Dlategc na tym miejscu wymienimy kilka dat obrazujących działalność Profesora w tym kierunku:

24 Tamże, s. 6.

${ }^{25}$ List $z 15$ października 1946, Archiwum XX. Misjonarzy na Stradomiu (AMS). 26 - Analecta Cracoviensia 
- W roku 1949, dzięki staraniom Profesora Usowicza, ukazało się pierwsze wydanie dzieła Między heroizmem a bestialstwem.

- W roku 1950, wspólnie z Romanem Ingardenem, przygotował do publikacji francuski tekst Gnozeologii Dantego. Obecnie przygotowuje pełny - dotychczas jeszcze w całości nie drukowany - tekst tej książki w języku polskim. Zdaniem Profesora, tekst ten będzie bardziej pełny i autentyczny aniżeli tekst francuski.

- W tym samym roku 1950 przygotował do druku podwójny numer „Polonia Sacra” obejmujący wyłącznie teksty wybrane ks. Michalskiego, w tym także trzy teksty wyjęte z Gnozeologii Dantego ${ }^{28}$.

- W roku 1979 ukazał się wybór tekstów pod tytułem Nova et vetera. Teksty w tym zbiorze zgrupowano wokół czterech tematów: sprawności etyczne, sapientia christiana, życie religijne i dzieje narodu.

- W roku 1980 ukazał się drukiem tekst pt. Zmiany postawy religijnej na przełomie XIX $i X X$ w., przygotowany do publikacji przez Księdza Profesora ${ }^{27}$.

- W roku 1982 ukazał się niewielki tekst pt. W poszukiwaniu kultury, także opracowany przez Profesora ${ }^{28}$.

- W roku 1982 ukazał się również wybór prac pt. Spotkanie z prawda, wybór dokonany przez Profesora przy współpracy ks. Jana Dukały.

- W roku 1984 opracowal, z dużym nakładem pracy, drugie wydanie Między heroizmem a bestialstwem. $\mathrm{Z}$ inicjatywy Romana Ingardena, a potem dzięki staraniom również innych osób, miały się ukazać drukiem dzieła ks. Michalskiego z zakresu filozofii średniowiecznej. Redakcję tej edycji, według projektu, powierzono Profesorowi przy współpracy sekcji historii filozofii starożytnej i średniowiecznej Polskiej Akademii Nauk. W roku 1958-59 były widoki na opublikowanie tych dzieł. Bez winy inicjatorów projekt powyższy nie został zrealizowany ${ }^{2}$.

W drugiej grupie prac możemy wyodrębnić dział systematyczny oraz dział historyczny, chociaż i tutaj granica między tymi działami nie jest zbyt wyraźna. W dziale systematycznym można wyróżnić trzy ważniejsze zespoły tematów: zespół dotyczący kształtowania się osobowości, a więc artykuły związane z książkami wymienionymi już na miejscu drugim i trzecim, zespół odnoszący się do filozofii życia państwowego, a więc do polityki w tradycyjnym znaczeniu, wreszcie zespół tematów z zakresu filozofii religii.

W zespole pierwszym wymieńmy, jako ważniejsze, cztery artykuły. W pierwszym artykule, zatytułowanym Psychologia ascezy, autor oma-

\footnotetext{
26 „Polonia Sacra” 3(1950) zeszyt 3-4.

27 "Analecta Cracoviensia" 12(1980) s. 7-44.

28 „Analecta Cracoviensia” 14(1982) s. $227-229$.

29 Zob. S. S wi ezawski, Pro memoria, AMS.
} 
wia najpierw znamiona ascezy zdrowej, by następnie opisać kierujące nią prawa psychologiczne. Zdaniem autora, w prawach tych przejawia się prymat przedmiotowości, prymat całości oraz prymat ewolucji twórczej. Prymat przedmiotowości polega na tym, że normalne życie psychiczne, w tym i zdrowa asceza, zmierza od jaźni, od czynników podmiotowych $\mathrm{ku}$ wartościom przedmiotowym, kieruje się ku osobom i ku grupie społecznej. W ten sposób znika niebezpieczeństwo egocentryzmu. Prymat całości wykazuje, że normalne życie psychiczne i zdrowa asceza zmierzają $\mathrm{ku}$ integracji, ku scaleniu, podczas gdy życie psychiczne odchylone od normy jest pewnym rozprzężeniem energii i tendencji. Wreszcie, w zdrowej ascezie pojawia się prymat ewolucji twórczej. Ewolucja ta kieruje się ku spełnianiu obowiązku, realizacji jakiegoś ideału i w ogóle powiększaniu wartości zarówno przedmiotowych jak i podmiotowych. Dlatego osobowość ascety nie ulega zubożeniu, lecz przeciwnie - wzbogaceniu. Artykuł kończy się następującymi słowami: „Z powyższych danych wynika, że typ ascezy chrześcijańskiej jest typem odmiennym od ascezy stoickiej. Asceza stoicka jest typem zamkniętym i jako taka prowadzi łatwo do anomalii i schorzeń psychicznych. Typ ascezy chrześcijańskiej natomiast jest typem otwartym, typem, który nie zamyka dróg do zdobycia pozytywnych wartości, lecz przeciwnie - odkrywa je i wskazuje. Toteż asceza chrześcijańska nie tyle mówi o wyrzeczeniu się, ile raczej wprowadza hierarchię i harmonię w wartości ludzkie. Charakter jej jest wybitnie humanistyczny" s0.

Drugi artykuł w tym zestawie tematów nosi tytuł Eros $i$ caritas. Autor omawia tu trzy odmiany miłości: eros, caritas i przyjaźn. M.in. artykuł wskazuje na różnice zachodzące między eros i caritas. „Eros najpierw jest miłością spontaniczną, caritas zaś miłością, która łączy się z wyborem przedmiotu dążenia [...]. Eros dalej oznacza miłość interesowną, która pragnie korzyść odnieść z przedmiotu czy osoby miłowanej. Caritas zaś jest miłością, która niesie innym dary, a nawet składa ze siebie ofiarę [...]. Eros wreszcie jest raczej dążeniem niższego ku wyższemu, caritas natomiast jest przede wszystkim zbliżaniem się wyższego ku niższemu. $\mathrm{Na}$ tę cechę caritas zwrócił uwagę we współczesnej filozofii Max Scheler" ${ }^{31}$.

W trzecim artykule, zatytułowanym Dynamika uczuć w psychologii tomistycznej, autor nawiązuje do współczesnego podziału uczuć na: afekty, namiętnośści i nastroje, wymienia nadto w szczególny sposób dwie struktury psychiczne, podziw i zainteresowanie, struktury o silnym zabarwieniu uczuciowym. Po omówieniu afektów, namiętności i nastrojów, tak jak one się przedstawiają w psychologii św. Tomasza, przechodzi do scharakteryzowania podziwu i zainteresowania, nawiązując do współczesnej dy.-

\footnotetext{
80 "Przegląd Powszechny” 1949, t. 228 s. 376-385.

31 "Tygodnik Powszechny" 7(1951) nr 44 s. 3.
} 
daktyki. „Zainteresowanie, zdaniem autora, o ile jest sprawnością nabytą, nosi u św. Tomasza nazwę studiositas. Studiositas reguluje pragnienie wiedzy. Pragnienie skłania umysł do skupienia uwagi nawet na danym przedmiocie, którym się umysł zajmuje, a tym samym pobudza do intensywnej pracy intelektualnej, umożliwiając równocześnie pokonywanie trudności związanych z pracą. Z drugiej strony studiositas wprowadza taki umiar w pragnienie poznania, że ono nie wyradza się w jakiś żywiołowy pęd w kierunku poznawania w formie niezdrowej ciekawości”. Kończąc artykuł, autor daje krytyczną uwagę odnoszącą się do Nietzschego: „Nietzsche postawił zarzut, że myśl chrześcijańska nie zna pojęcia uduchowienia uczuć zmysłowych, że nigdy nie umiała prowadzić inteligentnej walki przeciwko namiętnościom i że faktycznie zawsze głosiła tezę o konieczności bezwzględnego wykorzeniania uczuć, stając się tym samym wrogiem życia. Wystarczy przeczytać teksty św. Tomasza, odnoszące się do dynamiki uczuć, by się przekonać, że Nietzsche albo zupełnie nie rozumiał idei chrześcijańskiej, albo też zetknął się z wypaczoną, nieautentyczną postawą wobec uczuć" 32 .

Czwarty artykuł z wymienionego zespołu tematów omawia zjawisko psychastenii. Zdaniem autora, zjawisko to, ,jak sama nazwa wskazuje, polega na większym lub mniejszym stopniu osłabienia władz duszy ludzkiej i ich funkcji". W artykule uwzględniono fenomenologię, czyli objawy reakcji psychastenicznych, dalej etiologię, a więc przyczyny psychastenii oraz psychoterapię, tzn. środki lecznicze ${ }^{33}$.

Z powyższym zespołem tematów wiążą się organicznie dwa inne artykuły: Nadzieja religijna ${ }^{34}$ oraz Smutek ubogiego ${ }^{35}$, które stanowią analizę odpowiednich tekstów św. Tomasza. Do tematyki wymienionego zestawu zagadnień nawiązują także inne artykuły jak również i recenzje książek ${ }^{36}$.

W drugim zestawie tematów mieszczą się artykuły omawiające problematykę z zakresu filozofii państwa. Artykuły te poruszają wiele myśli. Wymieńmy ważniejsze:

Zasady ustroju państwowego. W artykule, noszącym taki tytuł, autor wymienia dwie zasady ustroju państwowego. Według pierwszej zasady „,najdoskonalszym ustrojem jest ten, który najlepiej odpowiada charakterowi danego narodu (Polit. III, 17). Według tej zasady błądzi ów prawodawca, który dosłownie przenosi ustrój jednego państwa na drugie. Mówiąc konkretnie, nie należy ustroju, który jest dobry np. dla zrównoważonego z natury i kierującego się głównie rozsądkiem Anglika, przenosić

\footnotetext{
32 „Analecta Cracoviensia” 1(1969) s. 21-31.

33 "Głos Karmelu" 19(1950) nr 6 s. $23-29$.

34 "Głos Karmelu” 21(1952) nr 1 s. 6-10.

35 "Caritas" 3(1947) nr 3 s. $62-65$.

36 Por. „Polonia Sacra” 2(1949) s. 91-93.
} 
na teren zamieszkany przez ruchliwych i pełnych gorącego uczucia Polaków. Narody bowiem, podobnie jak i jednostki, obok wspólnych cech natury ludzkiej, mają i cechy im tylko właściwe i niepowtarzalne. Dlatego wkładać wszystkie narody w jedną i tę samą formę ustrojową, znaczy zamykać ich w więzieniu i utrudniać im swobodę rozwoju". Druga zasada ustrojowa podkreśla znaczenie uczestnictwa w kierowaniu państwem. ,Najlepszym ustrojem jest ten, w którym wszyscy biorą udział w rządach (Polit. III, 14). Zasada ta opiera się nie tyle na równości między ludźmi, ile raczej na godności osobistej każdego. Gdzie bowiem zbytnio podkreśla się równość, wspólną płaszczyznę i szarzyznę życia, tam zachodzi obawa uznania wszystkich jedynie za ogniwa i bierne pionki w potężnym mechanizmie państwowym. Uszanowanie zaś osobistej godności, przyznanie każdemu obywatelowi rozumnie pojętej wolności, prostą drogą prowadzi do upowszechnienia udziału w kierowaniu państwem" ${ }^{37}$.

Władza w państwie. W artykułach w dziale systematycznym (a także i w dziale historycznym) często pojawia się myśl nawiązująca zwłaszcza do filozofów średniowiecza, która akcentuje rolę władzy państwowej jako służby narodowi. „Filozofowie średniowiecza ujmują władzę nie tyle jako godność, ile raczej jako obowiązek — officium. Ponieważ życie społeczne nie ma innej racji bytu jak tylko rozwój osobowości wszystkich obywateli, dlatego w pojęciu każdej władzy państwowej kryje się idea służby poddanym. Nie człowiek, jako ogniwo państwa, jest w służbie rządu, lecz rząd w służbie obywateli [...]. W związku z tym, pisze autor dalej, średniowieczna myśl polityczna bardzo ostro krytykuje tyranię uważając ją wśród wszystkich wypaczonych form rządu za najgorszą i najszkodliwszą. Dante w swym Piekle umieszcza tyranów w specjalnym miejscu, wśród rozbójników i morderców. Wszystkie traktaty polityczno-pedagogiczne, pisane dla królów lub przyszłych królów, odrzucają zasadę o arbitralnym wykonywaniu władzy. Sw. Tomasz potępia zabójstwo tyrana, pragnie, ażeby cierpliwość obywateli posuwała się do granic ostatecznych; jeżeli jednak rządy staną się niemożliwymi do zniesienia, przyznaje poddanym prawo depozycji. Depozycja w tym wypadku nie ma cech rokoszu, rokoszaninem jest raczej sam tyran, który w narodzie sobie poddanym wznieca niezgodę i bunty" ${ }^{38}$.

Kapitał $i$ praca. Ksiądz Profesor powracał nieraz do niektórych zagadnień etyki społeczno-gospodarczej, akcentując szczególnie jej charakter humanistyczny. Nawet wykład habilitacyjny nosił tytuł Charakter humanistyczny etyki społecznej św. Tomasza z Akwinu. W związku z tym omawiał w artykułach również zagadnienie kapitału i pracy. Zdaniem Profesora, ,liberalizm ekonomiczny, jako cel gospodarki postawił zysk,

37 "Tygodnik Warszawski” 2(1946) nr 30 s. 1.

38 „Roczniki Filozoficzne” 1(1948) s. 278-281. 
jak największe gromadzenie bogactw. Nieograniczona produkcja usunęła na dalszy plan człowieka. Człowiek w tym systemie, zamiast być miarą kapitału, stał się jego sługą, często niewolnikiem i ofiarą. A ponieważ istota rozumna i wolna nie może na dłuższą metę znieść podeptania swych praw, dlatego liberalizm ekonomiczny doprowadził rychło do buntu sponiewieranego człowieczeństwa. Buntem tym był socjalizm. W przeciwieństwie do liberalizmu, chrześcijańska etyka społeczna uczy, że celem gromadzenia zysku jest zaspokojenie potrzeb ludzkich, umożliwienie wszystkim takiego życia, jakie jest godne człowieka. Nie człowiek więc jest w służbie kapitału, lecz kapitał w służbie człowieka". Profesor, analizując myśl św. Tomasza, wypowiada się na temat celowości pracy ludzkiej. Pierwszym celem pracy jest zdobycie utrzymania. Ten cel, pozornie prosty i prozaiczny, spełnia ważną rolę nie tylko w zakresie somatycznym, ale także psychicznym i moralnym, zarówno gdy chodzi o charakter osoby indywidualnej jak i o znamiona duszy zbiorowej narodu. „Drugim celem pracy jest zachowanie równowagi wewnętrznej [...]. I praca ręczna bowiem może dodatnio wpływać na równowagę psychiczną. Wobec tego nędza bezrobocia nie tylko polega na braku środków do życia, lecz także na braku niezbędnego środka dla zachowania wewnętrznego dobrobytu człowieka [...]. Także i trzeci cel pracy ma zabarwienie humanistyczne. Praca ma pozostawić pewien nadmiar, pewną nadwartość, przeznaczoną na pomoc dla tych, którzy pracować nie mogą i znajdują się $\mathrm{w}$ biedzie. W ten sposób w życie gospodarczo-społeczne wprowadza chrześcijańska etyka społeczna drugi obok sprawiedliwości motor, mianowicie cnotę miłości" ${ }^{39}$.

Okres przełomowy. W artykule tym, autor, wychodząc od pewnych wydarzeń w naszym kraju, analizuje niektóre teksty filozofów greckich odnoszących się do momentów przełomowych w życiu narodów. W charakterystyce okresu przełomowego m.in. interpretuje odpowiednio mit prometejski Platona, dając nieco inne jego tłumaczenie aniżeli to, które powszechnie pojawia się $\mathrm{w}$ komentarzach do platońskiego Protagorasa. Autor korzysta też z tekstu Bergsona, by odnieść cechy przypisane przez Bergsona mistykom do liderów w okresie przełomowym. W ostatnim fragmencie artykułu autor przeprowadza porównanie między okresem przełomowym a rewolucją. Pisze: „Postawmy jeszcze pytanie, czy okres przełomowy typu kairos może być nazwany rewolucją. Odpowiedź zależy od tego, jakie poda się określenie procesów rewolucyjnych. Autor Etyki solidarności tak pisze na temat rewolucji: „Rewolucja, która jest wydarzeniem w świecie ducha, jest tym bardziej autentyczna, im bardziej jest bezkrwawa. Duch włada poprzez perswazję, a nie poprzez strach. Dlatego naprawdę wielka rewolucja jest zarazem świętem wyzwolenia człowieka

${ }^{39}$ W obronie człowieka, "Tygodnik Wanszawski" 2(1946) nr 26 s. 1-2; por. Czynniki sktadowe życia zbiorowego, „Polonia Sacra” 2(1949) s. 340-346. 
od strachu przed człowiekiem". Przyjąwszy takie określenie rewolucji, w pewnym znaczeniu nobilitowanej, można postawić znak równania między kairos a rewolucją. Ale jest jeszcze inne, potoczne określenie procesów rewolucyjnych. Według tego określenia, rewolucja jest najwyższą formą walki klas. Między rewolucją tak pojętą a kairos występują znaczne różnice" ${ }^{40}$.

Mówiąc o trzecim zespole tematów - odnoszącym się do filozofii religii - zwróćmy uwagę na dwa artykuły. Artykuł pt. Wspótczesna filozofia religii omawia przedmiot filozofii religii, jej metody, problem istnienia jako odrębnej dyscypliny i tym podobne tematy. Charakteryzując metodę filozofii religii, autor podkreśla m.in. znaczenie pewnej postawy filozofa. „Uzupełnieniem wymienionych metod jest metoda, albo raczej postawa ducha, którą możemy nazwać egzystencjalną. Religia jest zjawiskiem, które dotyka najgłębszych pokładów istnienia ludzkiego, dlatego podejście do niej nie może być czysto rzeczowe, chłodne, bezinteresowne. Wyrażając się terminologią szkoły würzburskiej powiemy, że nie postawa zamknięta, lecz otwarta może dać filozofii religii pozytywne rezultaty. Niebezpieczeństwo, jakie się łączy z podejściem pełnym szacunku przy rozumowym ujmowaniu religii, dostatecznie usuwa krytyczny z natury rzeczy charakter filozofii".

Autor artykułu zastanawia się także nad zarzutami, jakie się stawia filozofii religii, starając się $w$ krótkich słowach ocenić je krytycznie. „Przeciwko istnieniu filozofii religii postawiono liczne zarzuty, tak ze strony filozofii jak i religii. Niektórzy filozofowie twierdzą, że religia jest czymś irracjonalnym, czymś, czego nie da się ująć w pojęcia i kategorie. Religia więc uchyla się przed pracą badawczą rozumu. Zarzut ten zapoznaje fakt, że religia zawiera $\mathrm{w}$ sobie element racjonalny, jak to wykazuje m.in. historia religii ludów pierwotnych. Zresztą, gdyby nawet religia była czymś irracjonalnym, mogłaby istnieć filozofia religii, badaniu bowiem rozumowemu podlega wszystko, co ludzkie, nawet stany uczuciowe. Sztuka nie jest sylogizmem, ani też teorią, a jednak istnieje filozofia sztuki, która może podsunąć wartościowe idee także artystom". Zdaniem autora, jeszcze ważniejsze zarzuty stawia pod adresem filozofii religii sama religia. „Religia jest zetknięciem się ze świętością i nieskończonością, nie może więc stać się przedmiotem teoretycznych badań lub ciekawości ludzkiej. Stawiać religię przed trybunałem rozumu ludzkiego byłoby pewnego rodzaju świętokradztwem. Trzeba jednak pamiętać, że filozofia religiii nie chce osądzać religii, lecz tylko ją poznawać [...]. Nikt chyba nie posądzi wielkich filozofów średniowiecza o brak szacunku

40 „Analecta Cracoviensia” 14(1982) s. 231-242; J. Ti c h ner, Etyka solidarności, Kraków 1981, s. 61. 
dla religii, a jednak, jak w rzadko którym okresie, badano wówczas rozumowo religię" ${ }^{41}$.

Drugi artykuł - Człowiek religijny - bierze pod uwagę cechy istotne przeżyć religijnych, by następnie szerzej omówić typologię religijną. $\mathrm{W}$ artykule uwzględniono typologię Williama Jamesa (dusze raz urodzone i dwukrotnie urodzone, optymiści i pesymiści), typologię Fryderyka Heilera (mistyk i działacz religijny), typologię Ryszarda Müller-Freienfelsa (religijność emocjonalna i racjonalna) i wreszcie typologię Ericha Przywary (typ uczuciowy, kontemplacyjny i woluntarystyczny). Artykuł konczy się następującą refleksją: „Psychologia religii empiryczna, opisując istotne cechy przeżyć religijnych i ich przejawy w różnych typach, nie wychodzi zasadniczo poza stronę zjawiskową. Gdybyśmy jednak chcieli pójść daleị, przekraczając właściwe psychologii doświadczalnej oranice, to $\mathrm{w}$ oparciu o zasadę racji wystarczającej moglibyśmy wnioskować, że faktów powyższych nie można zrozumieć inaczej, jak przez przyjęcie Bytu transcendentnego. Arystoteles powiedział, że ruch nieba i ziemi zawisł niejako na istnieniu Pierwszego Motoru. My z równą słusznością możemy powiedzieć, że poruszenia duszy religijnej nie mogą być zrozumiane inaczej, jak tylko przez przyjęcie tezy o istnieniu Boga" ${ }^{42}$.

W dziale historycznym mamy szereg artykułów o różnym profilu. Niektóre z nich mają charakter wybitnie erudycyjny, wypełnione są datami, faktami, tytułami dzieł. Do takich np. należy artykuł o księdzu Franciszku Gabrylu ${ }^{43}$ lub o Grzegorzu ze Stawiszyna, napisany wspólnie $\mathrm{z}$ Leszkiem Hajdukiewiczem ${ }^{44}$. Inne artykuły mają bardziej swobodną formę i, choć nie tracą swego charakteru historycznego, są raczej artykułami ideowymi, zbliżonymi do działu artykułów systematycznych. W artykułach tych autor wychodzi zwykle od jakiejś idei dawnych filozofów, najczęściej Platona, Arystotelesa lub św. Tomasza z Akwinu i stara się następnie daną ideę uaktualnić. Nieraz postępuje odwrotnie, wychodzi z myśli współczesnej, cytuje np. Maxa Schelera, by potem odszukać podobną ideę w starożytności lub w średniowieczu.

Wśród artykułów wymienionego działu mamy sylwetki biograficzne. Autor stara się w nich podać życiorys, omówić dzieła itd. danej postaci. Sylwetki biograficzne kończą się zwykle zwięzłą charakterystyką osobowości i twórczości danego filozofa. W artykule np. o o. Jacku Woronieckim czytamy: „Twórczość o. Woronieckiego nie zacieśniała sie do szczupłych ram jednego wycinka wiedzy; przeciwnie, obejmowała szerokie horyzonty. Zagadnienia jednak, którymi się zajmował, umiał

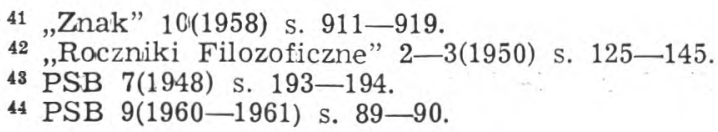


sprowadzać do pewnych centralnych, ośrodkowych problemów; nie były to zagadnienia rozrzucone, lecz sprzężone ze sobą w jedną całość. W ten sposób uniknął jednostronności specjalistów, owego jak gdyby daltonizmu duchowego, a z drugiej strony niebezpiecznej powierzchowności. Nie wszystkie idee, które poruszał, od razu znajdowały swych zwolenników: wszystkie jednak miały żywy oddźwięk, zmuszały do myślenia, do zmiany utartych poglądów, względnie do sformułowania innych, odrębnych idei. Dlatego wkład o. Jacka w polską kulturę katolicką jest niewątpliwie wkładem pozytywnych, trwałych i żywych wartości" ${ }^{45}$.

Podobnie postąpił autor $\mathrm{w}$ artykule o Stanisławie Wieczorkowskim (pierwsza połowa XVII w.), częściowo opartym na rękopisie Archiwum Stradomskiego. Pod koniec artykułu zjawia się ocena działalności Wieczorkowskiego: „Działalność Wieczorkowskiego jest typowym przykładem działalności magistrów krakowskich z pierwszej połowy XVII w. Prace tych magistrów poruszają wprawdzie głębokie zagadnienia, ale będące objawem wspólnego dziedzictwa scholastyków. Trzeba uszanować te prace, jako wyraz gromadzenia prawdy kropla po kropli trudem wielu pokoleń, ale nie można w całości ich naśladować, bo trzeba stare rzeczy wiązać z nowymi" ${ }^{46}$.

W artykułach historyczno-ideowych nacisk położony jest na poglądy danego autora, przy czym piszący stara się odczytać $\mathrm{w}$ tych poglądach takie idee, które jego zdaniem są żywotne i dzisiaj. Np. w artykule o traktatach Jana z Głogowa podkreśla ocenę przeszłości występującą w myśli Głogowczyka, która to ocena jest zarazem przejawem kultury wieków średnich. Jan z Głogowa jako polihistor czerpie $\mathrm{z}$ najbardziej różnorodnych źródeł, ,ażeby z nich wydobyć cząstkę prawdy. Zależnie od celu pracy podstawą jest ten lub inny autor. Obok niego jednak cytuje cały szereg różnorodnych powag, tak że mamy u Głogowczyka przegląd wszystkich niemal opinii odnośnie kwestii roztrząsanej". Jeden z rozdziałów artykułu zatytułowany jest Laudes creatuarum. W rozdziale tym autor opisuje nastawienie do przyrody w poglądach Głogowczyka i stwierdza, że pojawia się $w$ nich trojakie podejście do przyrody żywej i martwej: realne, etymologiczne i symboliczne, co jest także cechą charakterystyczną kultury średniowiecznej ${ }^{47}$.

Inny artykuł, pt. Poglady moralno-polityczne księdza Stanisława Sokołowskiego, omawia m.in. przyczyny upadku narodów oraz zagadnienie wolności i jej granic. Autor szkicując ten drugi temat, mówi także o wolności powszechnej: „Wolność ma być dobrem nie dla jednej tylko prowincji Rzeczypospolitej lub dla jednej tylko grupy ludzi; ma być podzie-

45 „Przegląd Powszechny” 1949, t. 228 s. 121-133.

46 "Nasza Przeszłość" 3(1947) s. 145-161.

47 "Nasza Przeszłość" 4(1948) s. 125-156. 
lona proporcjonalnie między wszystkich. Każdy obywatel powinien tak ochraniać swą wolność, ażeby jego prawa nie znosily uprawnień bliźniego. Dobro wolności jest własnością całego ciała; między wszystkie więc członki, według odpowiedniej proporcji, powinna być rozłożona. Jeśli tego nie będzie, wolność zaniknie, a pojawi się obopólna niewola". Dalej uwypukla autor $-\mathrm{z}$ widoczną, chociaż niewyraźnie wypowiedzianą aprobatą - myśl Sokołowskiego następująco: „Cóż to za wolność Rzeczypospolitej, w której jeden stan ma wszystkie prawa za sobą, a żadnych przeciwko sobie, i gdzie każdy mniema, że nie może zachować swej wolności, o ile nie uszczupli wolności drugiego. Co to za wolność, gdzie jeden panuje, a drugi nie ma nawet możności przedstawić swej sprawy sądowi. Jeden podług swej woli czyni wszystko, a drugiemu nawet jęczeć nie wolno?" ${ }^{48}$.

W trzeciej grupie, jak powiedzieliśmy, mieszczą się drobne dialogi. Dialogi te są anonimowe, chociaż znani są ich autorzy. W pierwszym numerze „Meteora”, ukazującego się wtedy w normalnym druku, redakcja czasopisma zapowiada nowy dział, który będzie zatytułowany Athalos. Znajdujemy tam również krótką charakterystykę tego nowego działu: „Athalos to uosobienie niespokojnej myśli i nieśmiertelnej duszy ludzkiej, szukającej wszędzie prawdy i szczęścia. Athalos jest nowym działem „Meteora”; nowym pod względem formy i treści. Pod tym tytułem będą pojawiać się w naszym pisemku dialogi [...] zwięzłe, krótkie, skąpe w słowa, bogate w myśli. Wielkie duchy ludzkości będą występować w Athalosie, będą roztrząsać zagadki bytu". Inicjatorem i autorem sześciu pierwszych dialogów był właśnie Ksiądz Profesor Usowicz. Dwa pierwsze dialogi, poza ogólnym tytułem Athalos, nie mają odrębnego tytułu. Cztery dalsze posiadają odrębny, własny tytuł. W pierwszym dialogu Athalos rozmawia z Sokratesem ,na temat poważny, a tak dobrze znany każdemu człowiekowi, na temat cierpienia". W drugim tekście Athalos prowadzi dialog z Miriam (Marią). Dialog jest pewnego rodzaju kontynuacją myśli pierwszego dialogu, gdyż mowa tu o znaczeniu cierpienia i ofiary. Trzeci dialog posiada tytuł Finis comoediae. Athalos prowadzi tu rozmowę $\mathrm{z}$ Wolterem na temat powagi i prawdy życia ludzkiego. W czwartym tekście, zatytułowanym Swiat drobnoustrojów, Athalos rozmawia z Fryderykiem Wilhelmem Foersterem nt. roli i znaczenia tzw. małych rzeczy. W piątym dialogu pt. Spiżowe posągi pojawia się Savonarola i dyskutuje z Athalosem. Przedmiotem dialogu są niezłomne charaktery. W szóstym dialogu, noszącym tytuł Przekleństwo szczytów, Athalos rozmawia z Newmanem. Rozmowa dotyczy niebezpieczeństw związanych $\mathrm{z}$ dążeniem do „szczytów”.

48 „Nasza Przeszłość” 1(1946) s. 97-126. 
Aby lepiej pokazać styl i treść wymienionych dialogów, podajmy tu w całości najmniejszy $\mathrm{z}$ tekstów, zatytułowany Siwiat drobnoustrojów: ${ }^{40}$

F.W. Foerster: Potęga istot maluczkich zastanawia mnie. Spójrz, oto wyrzucono na brzeg morski zniszczony kadłub okrętu. Pyszczki milionów drobnych żyjątek przegryzły dno olbrzymiej łodzi.

Athalos: A tam w dali rysują się na błękicie nieba wyspy, zbudowane przez nikłe polipy koralowe. Naprawdę trzeba podkreślać wielkość, zawartą w małem.

F.: Mikroskopijne twory budzą podziw u prostaczków, pochłaniają wiele czasu przyrodnikowi, myśliciela zaś uczą cenić to wszystko, co niepozorne w stosunkach ludzkich. Swiat drobnoustrojów stawia przed oczy male czyny, uwypukla ich wartość, oraz zaklętą w tzw. drobmostkach uczciwość i poświęcenie. Milimetr powietrza i kropla wody z właściwym sobie życiem uczy nas, że możemy być bohaterami bez przygrywki upojenia i powszechnych oklasków. Trudniej jest czasem być odważnym i cnotliwym w szczupłym kółku rodzinnym niż na polu chwały, gdzie huczy muzyka pulkowa, a potem rozdają krzyże zasługi.

Kiedy Ksiądz Profesor pisał powyższy dialog, miał zaledwie 22 lata. Można więc uznać, że w jakiejś mierze nakreślał w nim swój życiowy program oraz dokonywał wyboru swych ideałów. Z zarysowanego w niniejszym artykule obrazu pracowitego życia Księdza Profesora, wyraźnie widać Jego niezwykłą konsekwencję w realizowaniu owego młodzieńczego programu oraz Jego bezwzględną wierność ideałom Athalosa. Słowa, które niegdyś włożył Ksiądz Profesor w usta Athalosa, zatoczyły potężne koło i wracają dziś w postaci zdumienia malującego się na twarzach długiego szeregu Jego uczniów. Wszyscy oni, spoglądając na zwyczajną, zawsze jakby usiłującą się ukryć sylwetkę Księdza Profesora, powtarzają za Athalosem: „Naprawdę trzeba podkreślać wielkość zawartą w małem”.

\section{LA LEGENDE D'OREE ET LA REALITE}

Cinquantenaire de l'activité scientifique et didactique de Professeur Aleksander Usowicz

\section{Ré s u m é}

L'article a deux parties. Dans la première partie l'auteur nous présente l'activité didactique de Professeur principallement en plusieurs Grands Seminaires et aussi à l'Université de Cracovie (faculté de théologie).

Dans la seconde partie l'article nous donne les informations avec une évaluation méritorique sur l'activité scientifique de Professeur. Les oeuvres scientifiques de Professeur on peut classer en trois groupes: les oeuvres en forme des livres, les articles et les petits dialogues redigés à l'exemple des dialogues de Platon.

\footnotetext{
49 „Meteor” 26(1934) nr 1-6.
} 


\title{
A N E K S
}

SPIS WYKEADÓW WYGEOSZONYCH PRZEZ KS. PROF. A. USOWICZA

\author{
Instytut Teologiczny \\ Zgromadzenia Księży Misjonarzy w Krakowie
}

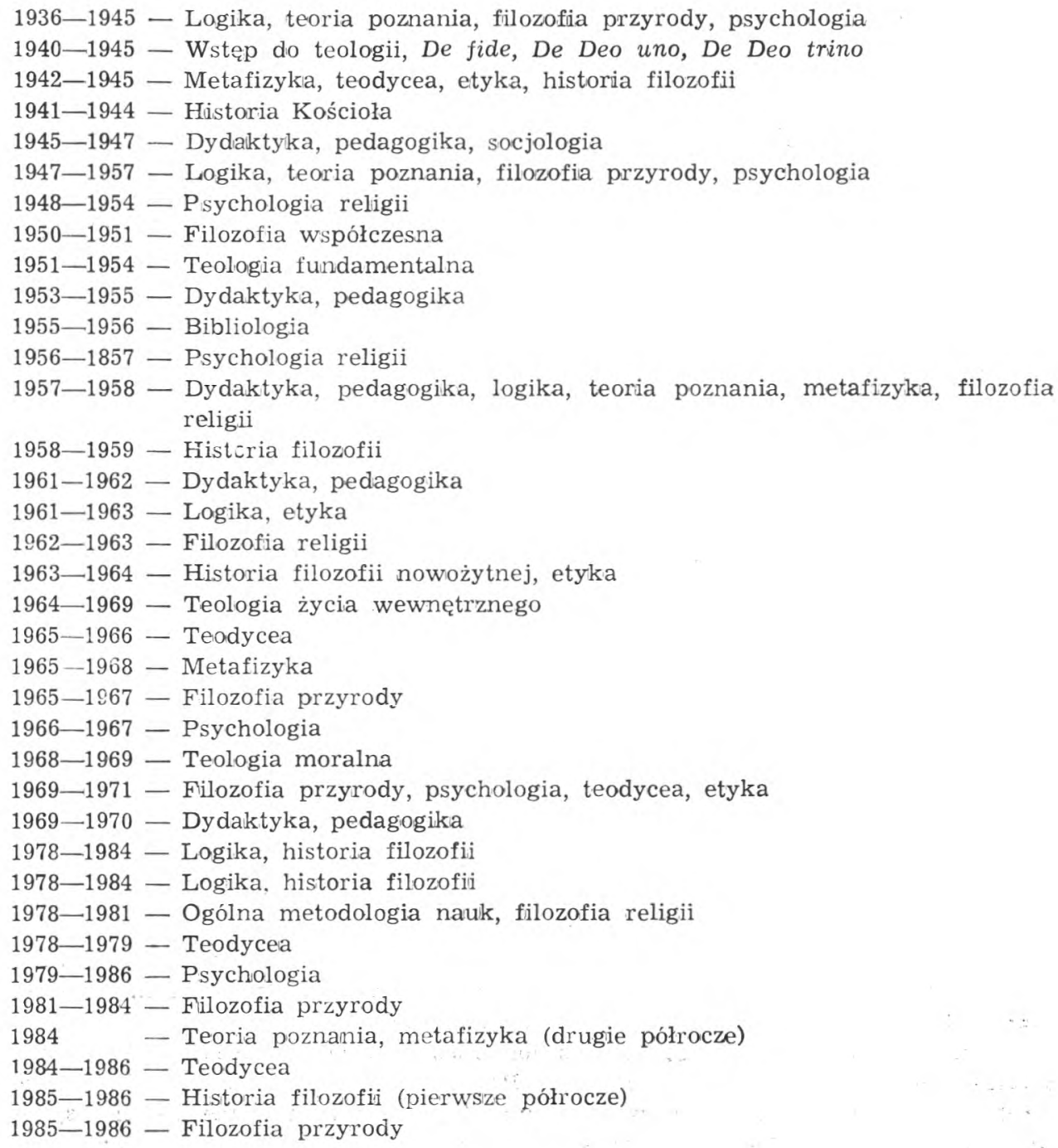




\section{Częstochowskie Seminarium Duchowne w Krakowie}

1939-1943 - Logika, teoria poznania, filozofia przyrody

1947-1956 - Psychologia, metafizyka, historia filozofii

1956-1959 - Psychologia, metafizyka

1965-1971 - Metafizyka

Wyższe Seminarium Duchowne Księży Salwatorianów w Krakowie 1940-1945 - Filozofia (z wyjątkiem historii filozofii)

\section{Wydział Teologiczny UJ}

1947-1948 - Psychologia ogólna, metafizyka, historia filozofii w zarysie

1948-1954 - Psychologia ogólna, psychologia religii, metafizyka, historia filozofil starożytnej i średniowiecznej

1949-1953 — Wstęp do teologii

\section{Seminarium Duchowne w Kielcach}

1950-1951 - Filozofia współczesna

\section{Seminarium Duchowne Ojców Kapucynów w Krakowie}

1952-1954 - Psychologia

\section{Sląskie Seminarium Duchowne w Krakowie}

1954-1959 - Psychologia, metafizyka, historia filozofii starożytnej i średniowiečnej

1965-1968 - Psychologia, metafizyka

\section{Wyższe Seminarium Duchowne Ojców Paulinów w Krakowie}

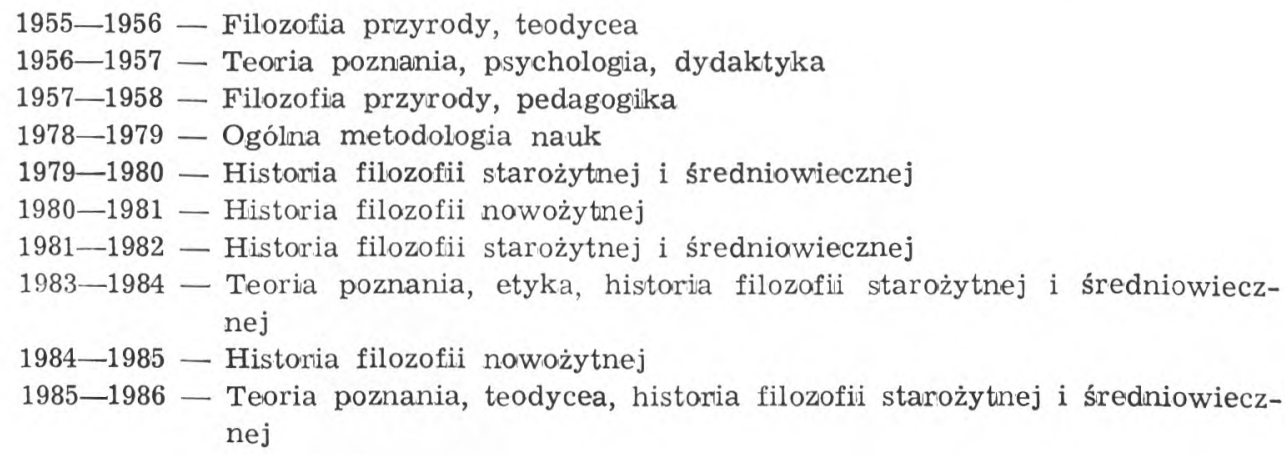


Papieski Wydział Teologiczny w Krakowie

1954-1959 - Psychologia, metafizyka, historia filozofii starożytnej i średniowiecznej

1965-1971 - Historia filozofii starożytnej i średniowiecznej

1965-1969 - Lektura tekstów filozoficznych

1966-1967 - Postawa człowieka wabec swiata (wykład monograficzny)

1978-1986 - Historia filozofii starożytnej i średniowiecznej

Biskupie Seminarium Duchowne w Gdańsku-Oliwie

1959-1961 - Patrologia, teologia fundamentalna, teologia moralna

1970 - Filozofia (drugie półrocze)

Gorzowskie Seminarium Duchowne w Gościkowie-Paradyżu

1971-1978 - Logika, teoria poznania, psychologia, metafizyka, historia filozofii

1971 - 1974 - Teodycea

1972-1975 - Antropologia filozoficzna

1974-1978 - Filozofia religii

Krakowska Uczelnia Teologiczna

Wydzial Filozoficzny

(wykłady monograficzne)

1981-1982 - Filozofia kultury (zagadnienia wybrane)

1982 - 1983 - Problem wojny i pokoju

1983-1984 - Zagadnienie praw człowieka

1984-1985 - Współczesny ateizm

1985-1986 - Etyka Nikomachejska 


\section{WYKAZ PRAC NAUKOWYCH KSIĘDZA PROFESORA ALEKSANDRA USOWICZA}

Poniższy wykaz składa się z dwóch części: część A obejmuje tytuły prac naukowych opublikowanych drukiem, część B - skrypty akademickie powielane.

\section{A}

1932

1. Wielki Swięty wielkiego wieku, „Meteor” 24(1932) s. 86-91.

\section{3}

2. Pismo i Platon, „Meteor” 25(1933) s. 67-68.

3. Znaczenie odsieczy wiedeńskiej, „Meteor” 25(1933) s. 153-157.

4. Athalos, „Meteor" 26(1934) s. 26.

5. W promieniach krzyża, „Meteor” 26(1934) s. 44-47.

6. Athalos, „Meteor” 26(1934) s. 56.

7. Finis comoediae (Athalos), "Meteor" 26(1934) s. 93.

8. Swiat drobnoustrojów (Athalos), „Meteor” 26(1934) s. 129.

9. Spiżowe posqgi (Athalos), „Meteor" 26(1934) s. 157.

10. Przekleństwo szczytów (Athalos), „Meteor” 26(1934) s. 194.

\section{8}

11. Przemówienie na wiecu „Meteora” (streszczenie), „Meteor” 30(1938) s. 220-221.

12. De Aristotelis circa definitionem doctrina commentatorum sententiis illustrata, "Collectanea Theologica" 19(1938) s. 273-317.

13. Miłość $w$ życiu św. Wincentego d Paulo, Kraków 1938.

1939

14. De partitione definitionis apud Aristotelem, „Divus Thomas” 42(1939) s. 114-119.

15. Układ cnót $i$ wad $w$ zwiqzku z życiem uczuciowo-popędowym u Arystotelesa i św. Tomasza $z$ Akwinu, Kraków 1939. 
16. Tomistyczna sublimacja uczuć w świetle nowożytnej psychologii, Kraków 1946.

17. Caritas a świat wspótczesny, "Caritas” 2(1946) $\mathrm{nr} 8 \mathrm{~s} .2-5$.

18. Zołnierz i kapłan, ,Tygodnik Powszechny” 2(1946) nr 2 s. 8.

19. W obronie człowieka, ,Tygodnik Warszawski” 2(1946) nr 26 s. $1-2$.

20. Wymowa katakumb, „Tygodnik Warszawski” 2(1946) $\mathrm{nr} 26$.

21. Zasady ustroju państwowego, "Tygodnik Warszawski” 2(1946) nr 30 s. 1.

22. Człowiek społeczny, „Caritas” 2(1946) ar 15 s. 10-17.

23. Poglady moralno-polityczne ks. Stanisława Sokołowskiego, „Nasza Przeszłość” $1(1946)$ s. $97-126$.

1947

24. Smutek ubogiego, „Caritas” 3(1947) nr 3(18) s. $62-65$.

25. Stanisław Wieczorkowski. Z dziejów Uniwersytetu Jagiellońskiego $w$ pierwszej połowie XVII w., „Nasza Przeszłość” 3(1947) s. 145-161.

26. Ksiądz Konstanty Michalski, „Niedziela” 17(1947) nr 34 s. 274.

27. Ksiądz Konstanty Michalski, „Homo Dei” 16(1947) s. 415-419.

28. Walka $z$ demonem alkoholizmu, „Caritas” 4 (1948) $\mathrm{nr} 3$ s. 69-70.

29. Traktaty Jana $z$ Gtogowa jako wyraz kultury średniowiecznej, „Nasza Przeszłość" 4/5(1948) s. 125-156.

30. Corpus philosophorum medii aevi, „Polonia Sacra” 1(1948) s. 185-192; 2(1949) s. $52-60$.

31. Gabryl Franciszek, [w:] Polski słownik biograficzny, t. 7(1948) 193-194.

32. Wladza państwowa w stużbie narodu, „Roczniki Filozoficzne” 1(1948) 278-281.

33. Ksiadz Konstanty Michalski, „Przegląd Filozoficzny” 1(1948) s. 428-435.

34. Nowożytne elementy $w$ średniowiecznych traktatach politycznych, „Polonia Sacra" 1(1948) $310-311$.

35. Rozpraw $z$ materializmem, „Tygodnik Powszechny” $4(1948)$ nr 50 s. 6.

1949

36. Przedmowa do: K. Michalski, Między heroizmem a bestialstwem, Kraków 1949, 5-8.

37. Zarys metafizyki ogólnej, "Tygodnik Powszechny” 5(1949) nr 17 s. $3-4$.

38. Recenzja: Ley A., Wauthier I. M., Etudes de psychologie instictive et affective, Paris 1946, „Polonia Sacra” 2(1949) s. 91-93.

39. 一, K. Kłós a k, Konstanty Michalski, Kraków 1949.

40. Dwaj mediewiści (M. Grabmann i M. De Wulf), „Polonia Sacra” 2(1949) s. 87-90.

41. O. Jacek Woroniecki, „Przegląd Powszechny” 1949, t. 228 s. 121-133.

42. Czynniki składowe życia zbiorowego, „Polonia Sacra” 2(1949) s. 327-349

43. Zlota legenda i rzeczywistość, "Caritas" 5(1949) nr 50 s. 322-324.

44. Psychologia ascezy, „Przegląd Powszechny” 1949, t. 228 s. 376-385. 
45. Slowo wstępne, „Polonia Sacra” 3(1950) 201-202.

46. Deum et animam cupio scire, „Polonia Sacra” 3(1950) s. 203-208.

47. Człowiek religijny, „Roczniki Filozoficzne” 2-3(1950) s. 125-145.

48. -, R. Ingarden, Avant-propos: K. Michalski, La gnoseologie de Dante, Kraków 1950, s. 3-5.

49. Zjawisko psychastenii w życiu wewnętrznym, „Głos Karmelu” 19(1950) s. 23-29.

\section{1}

50. Eros $i$ caritas, „Tygodnik Powszechny” 7(1951) nr 41 s. 3, 10.

51. Nadzieja religijna, „Głos Karmelu” 21(1952) s. 6-10.

\section{8}

52. Współczesna filozofia religii, „Znak” 10(1958) s. 911-919.

53. 一, L. Hajdukiewicz, Grzegorz ze Stawiszyna, [w:] Polski stownik biograficzny, t. $9(1960-1961)$ s. $89-90$.

54. Sapientia christiana, „Sląskie Studia Historyczno-Teologiczne” s. 2(1969) 9-18.

55. Dynamika uczuć w psychologii tomistycznej, „Analecta Cracoviensia” 1(1969) s. $21-31$.

56. Rozwój osobowości $w$ życiu zakonnym, [w:] Idee przewodnie konstytucji soborowej o Kościele, Kraków 1971, s. 117-129.

57. Listy Jana Łukasiewicza do ks. Konstantego Michalskiego, „Analecta Cracoviensia" 2(1971) s. 117-129.

58. Antropologia filozoficzna $w$ ujęciu Stefana Strassera, „Analecta Cracoviensia" $3(1972)$ s. $71-82$.

27 - Analecta Cracoviensia 
1973

59. Wspólczesne próby argumentacji za duchowościq duszy ludzkiej, [w:] Teologia a antropologia, Kraków 1973, s. 184-186.

60. Wstęp i wybór tekstów: K. M i c ha $1 \mathrm{ski}$, Nova et vetera, Kraków 1979.

1979

61. Ksiadz Konstanty Michalski, [w:] W nurcie zagadnień posoborowych, t. 4, Kraków 1979, s. $341-367$.

62. Przygotowanie do druku: K. Michalski, Zmiany postawy religijnej na przełomie XIX $i$ XX w., „Analecta Cracoviensia” 12(1980) s. 7-44.

1982

63. Okres przełomowy, „Analecta Cracoviensia” 14 (1982) s. 231-242.

64. Przygotowanie do druku: K. Michalski, W poszukiwaniu kultury, „Analecta Cracoviensia" 14(1982) s. 227-229.

65. -, J. Dukała, Wstęp i opracowanie: K. Michalski, Spotkanie z prawdq, Kraków 1982.

1983

66. Filozofia - teologia - historia, "Tygodnik Powszechny” 37(1983) nr 3 s. $7-8$.

1984

67. O autorze książki (wstęp i opracowanie), [w:] K. Michalski, Między heroizmem a bestialstwem, Częstochowa 1984, s. 3-23.

68. Przekaz informacji jako czynnik kulturotwórczy, [w:] Chrześcijaństwo a kultura polska, red. bp M. J a worski, ks. A. K ubis, Lublin (w druku).

Filozofia

1. Logika, 1941, ss. 76 .

2. Logika, 1957, ss. 71.

3. Logika, 1958, ss. 68 .

4. Ogólna metodologia nauk (wybór tekstów), 1978, ss. 126.

5. Kryteriologia, 1941 , s. $79-134$.

6. Teoria poznania, 1958, ss. 85 . 
7. Kosmologia, 1941, s. $137-206$.

8. Kosmologia, 1957, ss. 85 .

9. Filozofia przyrady, 1982, ss. 72 .

10. Psychologia, 1937, ss. 110.

11. Psychologia ogólna, 1948, ss. 118 (Wydawnictwo Koła Naukowego Teologów Sląskich UJ).

12. Zarys psychologii, 1950, ss. 105 .

13. Psychologia, 1957, ss. 163.

14. Psychologia, 1959, ss. 186 .

15. Psychologia religii, 1949, ss. 75 (Wydawnictwo Koła Naukowego Teologów Sląskich UJ).

16. Psychologia religii w zarysie, 1951, ss. 128.

17. Metafizyka ogólna, 1950, ss. 54.

18. Metafizyka ogólna, 1957, ss. 101.

19. Metafizyka, Gościkowo-Paradyż 1973, ss. 64.

20. Teodycea, 1966, ss. 60 .

21. Teodycea, 1979, ss. 72 .

22. Filozofia religii, 1957, ss. 68.

23. Etyka (ogólna i szczególowa), 1942, ss. 179.

24. Etyka (ogólna), 1982, ss. 56.

25. Filozofia starożytna i średniowieczna, 1958, ss. 103.

26. Filozofia nowożytna, 1957, ss. 80.

27. Filozofia współczesna, 1950, ss. 81.

28. Dydaktyka, 1953, ss. 40.

29. Dydaktyka, 1955 , ss. 61 .

30. Pedagogika, 1954, ss. 83.

31. Bibliologia, 1956, ss. 40.

Te ologia

32. Wstęp do teologii, 1941, ss. 70 .

33. Wstęp do teologii, 1948, ss. 45 (Wydawnictwo Koła Naukowego Teologów Sląskich UJ).

34. De fide, 1940 , s. $73-230$.

35. De fide, 1948 , ss. 55 .

36. Religia i objawienie, 1950 , ss. 56 .

37. Religia i objawienie, 1959, ss. 47.

38. De Christo legato, 1951, ss. 69.

39. De Christo legato, 1960 , s. $47-97$.

40. De Ecclesia, 1952, ss. 123.

41. De Ecclesia, 1954, ss. 92.

42. De Deo uno, 1941, ss. 137.

43. De Deo uno, 1949, ss. 79.

44. De Deo trino, 1941, s. $141-246$.

45. De Deo trino, 1950, ss. 49.

46. Kościół jako Ciało Mistyczne Chrystusa, 1944, ss. 86.

47. Kościół jako Ciało Mistyczne Chrystusa, 1959, ss. 80.

48. Podstawy teologii moralnej (Principia), Gdańsk-Oliwa 1960, ss. 130.

49. Teologia życia wewnętrznego (część systematyczna), 1966-1968, ss. 169. 
50. Historia teologii życia wewnętrznego, 1965, ss. 124.

51. Zgnomadzenie Księży Misjonarzy w tysiącleciu chrześcijaństwa Polski, 1965, ss. 44.

NB. Skrypty, przy których nie podano miejsca i instytucji wykonania, powstały w Krakowie, staraniem słuchaczy Instytutu Teologicznego Zgromadzenia Księży Misjonarzy. 